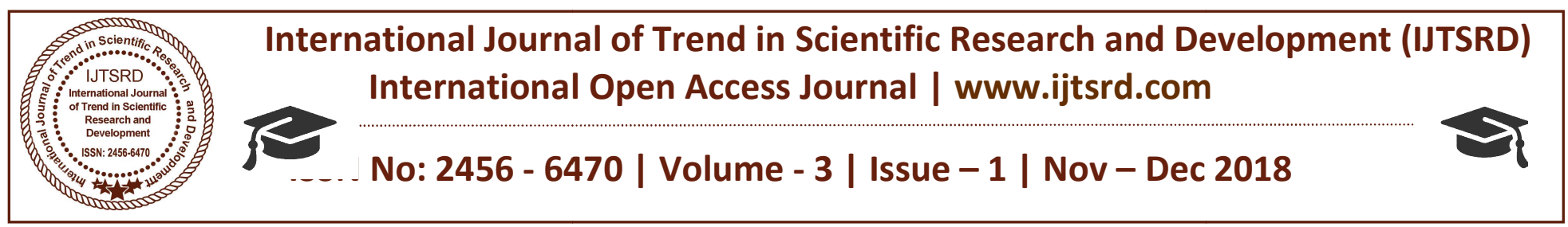

\title{
Analysis for Detection of Performance Characteristics of Diesel Fuel
}

\author{
Mohammed Nasiru Bello \\ Research Scholar, Department of Chemical Engineering, \\ University of Maiduguri, Borno State, Maiduguri, Nigeria
}

\begin{abstract}
Experimental analysis of properties of a diesel fuel plays an important role in delineating the performance and the reliability of the fuel. The objectives of this study are to assess the qualities of diesel fuel experimentally and to ensured that only diesel fuels that adhered to the standard specification requirements prescribed by the American Society for Testing Materials (ASTM) and that are in line with the standard specification requirements of the Department of Petroleum Resources (DPR) and the Standard Organization of Nigeria (SON) are allowed to reach the end users for utilization. In this study, ten samples of diesel fuel were randomly collected from
\end{abstract} different dispensing point. These samples were analyzed in the laboratory to determine their performances and properties. The properties of the diesel fuel samples that were determined in this study are; the appearance, colour, flash point temperatures, specific gravity, API gravity and the boiling points ranges of the samples. Among the aforementioned properties, the boiling point ranges is the most critical parameter that attest the reliability and the performance of the diesel fuel because it entails its state of purity. The results of this study for atmospheric distillation profile show that samples 1 to 7 met the minimum total recovery that is $97 \%(\mathrm{v} / \mathrm{v})$ and is the standard specification requirement prescribed by the Department of Petroleum Resources (DPR) and the Standard Organization of Nigeria (SON). This shows that samples 1 to 7 are unadulterated diesel fuel. However, samples 8 to 10 did not met the minimum total recovery of the $97 \%$ $(\mathrm{v} / \mathrm{v})$, their total recovery fall below the minimum standard criteria. This also indicates that samples 8 to 10 were adulterated by low quality products. These adulterated diesel fuel may not meet the engine requirement of a diesel powered vehicles. So, when these fake products are used as energy source in diesel

engine, it will reduce the performance of the engine. Therefore, adulterated products should not be allowed to reach the end user for utilization.

KEY WORDS: Diesel fuel, flash point temperature, Atmospheric distillation, Adulterated and Unadulterated diesel fuel.

\section{INTRODUCTION}

Petroleum is a natural occurring complex mixture of hydrocarbon that consist of liquid hydrocarbon (Crude oil) and gaseous hydrocarbon (natural gas). Crude oil consists of 200 or more mixtures of different organic compound. Most of these compounds are Alkanes with traceable amount of aromatics hydrocarbon (Devold, 2010). Inorganic compounds such as Sulphur, nitrogen and oxygen are also present in variable amount in crude oil compositions. Crude oils are broken into smaller fractions by fractional distillation in the refinery. These fractions can be used as fuels, lubricants, and or as intermediate feedstock for petrochemical industry (Jukic, 2009).

Diesel fuel is the product of fractional distillation of crude oil that is used as fuel in Diesel engines. In Diesel engine, the fuel is ignited by the heat of air compressed in the cylinder with the fuel injected in a spray into the hot compressed air not sparks as in gasoline engines ("Diesel fuel".2018). Diesel fuel produce more energy on combustion than the energy produces by equal volumes of gasoline which makes Diesel engines to be better fuel economy than gasoline engine ("Diesel fuel".2018). As compared with gasoline, diesel fuel require less refining process but releases more acidic gases like $\mathrm{CO}_{2}$ than gasoline. Diesel fuel is widely used in automobile, household appliance and in agricultural equipment (Bharath and Himanth, 2017). It is one of the fuel that keeps the world economy moving owing to it wide range of 
applications in power generation, on-road transportation, off road users (mining), construction and logging, Rail transportation, Marine shipping and Military transportation systems, all these sectors utilized diesel as their sources of energy, this makes the fuel to play vital roles in strengthening the global economy (Diesel fuel Technical Review, 2007).

Diesel fuel refinery processes: these are categorized into three;

Separation processes: these processes involve fractional distillation of crude oil that split the crude oil into smaller fractions bases on the boiling points of the crude oil compositions.

Upgrading processes: these processes involve the application of chemical reaction to remove the compounds that are presents in a traceable amount that gives the material an undesirable grade (Diesel fuel Technical Review, 2007).

Conversion processes: these processes involve cracking of large molecular feedstock with aid of catalyst or hydrocracking to change the fundamental molecular structure of the feedstock into smaller molecules. This fuel is associated with noise and the emission of particulates, trioxides and $\mathrm{CO}_{2}$.

Grade of Diesel fuel: Diesel fuel grade are as follows;

Land diesel fuel: typically used in trucks, buses, trains or other land transportation vehicles whose speed and load highly varies.

Marine diesel fuel: typically used in ships with variable speed but relatively high and uniform load (Yhu, 2000).

Plant diesel fuels: typically used in electrical power generation plant with loads that have medium or low speed. The quality or grade of these fuels depend on the engines performance requirements.

The market demand of diesel fuel differs from that of gasoline, owing to the fact that heavy duty trucks, construction and agricultural equipment, locomotive and commercial marine utilized diesel fuel while light duty cars and some trucks utilized gasoline.

Diesel is the second most consumed fuel in Nigeria. Statistical reports of petroleum products importation show that 1.3bilion liters of Automated Gas Oil (Diesel fuel) was imported to Nigeria in the first quarter of 2017 (Taiwo, 2017). And according to National Bureau of statistics, the average daily consumption of Diesel fuel in Nigeria was 12.72milion liters in 2017. The demand of diesel fuel increase with increase in economic activities that will result to additional freight or construction. This fuel demand also increase with increase in diesel powered vehicle such as trucks, SUVs, Vans and pickups, it increases from $13 \%$ in 2006 to $28 \%$ in 20011 according to recent studies. Today almost every filling station in the country sell diesel. This show that the demand of Diesel fuel is increasing every year. With increase in demand of this fuel, adulteration of this fuel by some marketers is becoming rampart so as to maximize their profits. If adulterated Diesel fuel is utilized as energy source in a Diesel power engine, it will reduce the performance of the engine and lead to emission of more poisonous gases to the environments. Therefore, it is necessary to checkmate the qualities of Diesel fuel that is being supplied to the consumers to ensure that the fuel properties are within the standard specification requirements of the American Society for Testing Materials (ASTM) by conducting a confirmatory analysis to attest the reliability of the products before it will be allow to reach the end user and this calls for the needs to carry out this study.

Quality assurance of Diesel fuel: is an analysis that is conducted in the laboratory to ensure that the Automated Gas Oil (Diesel fuel) is adhered the standard specification requirement of the American Society for Testing Materials (ASTM) before it will be allow to reach the end users for utilization. The parameters that are monitored in the quality control analysis are: boiling points, flash point, viscosity, density, cloud point, cetane number and cetane index, heating values, etc.

\section{Properties that determine the performance of Diesel fuel}

Boiling ranges: is the temperature between the initial boiling (IBP) and the final boiling point (FBP) that is determined to ensure the fuel products are suitable and volatile (Yhu, 2000). The ideal fuel volatility requirements will vary based on the size of the engine and it design, speed and load condition, and atmospheric condition (Change in Diesel fuel, 2007). This parameter can be obtained by ASTM D86. ASTM D2892 gives the true boiling point measurement using 15-theoretical plate columns. 
Viscosity: this is an important parameter that determined the performance of the fuel injection system, because some injection pumps can experience excessive wear and power loss due to injector or pump leakage when in contact with low viscous fuel. For a high viscous fuel, it can lead to severe pump resistance and adversely affect the fuel spray pattern and consequently damage the filter. According to ASTM D445, a fixed volume of fuel flows through a calibrated viscometer under a reproducible driving head at a close controlled temperature which determined the kinematic viscosity of the fuel.

Colour: this parameter is typically used for diesel quality identification. Variation outside the established range may signify degradation or contamination of the fuel with some products (Yhu, 2000). According to ASTM D1500 the specification range is from 0.5 to 8.0 which is the standard criteria for colour of diesel fuel.

Cetane: is one of the most important parameter that determined the performance of the diesel engine. It is the measure of ignition quality of fuel in the diesel engine. A diesel fuel with cetane number of 55 , matches the performance of a blend of $55 \%$ of $n$ hexadecane and $45 \%$ alpha-methylnepthelene in the cetane engine. The molecules with the highest cetane number are the straight chain normal paraffin. The molecules with lower cetane number are those that have few methylene groups. The presence of double bonds in a molecule will lower the cetane number of diesel fuel. Cetane number affects combustion roughness. In contrast to the octane number that measures the sparks ignition engines fuel ability to resist the engine knock. Diesel cetane rating works in opposite direction. The higher the cetane rating, the easier it ignites. The most common methods for determining cetane number are ASTM D976 and ASTM D4737. For diesel fuel, the minimum cetane number is 40 . The fuel should always meet this minimum specification requirement, because inadequate cetane number will lead to poor ignition quality, long ignition delay and abnormal combustion.

Cetane index: is the approximation of Cetane number based on the empirical relationship with density and volatility parameters. This is determined by ASTM D976.

Carbon residue: this test is conducted to determine the carbonaceous deposition tendency of diesel fuel in the engine. The maximum number of carbon residue is 0.35 mass percent for no.2 grade diesel. This analysis is determined by ASTM D482 and ASTM D524.

Sulphur content: this lead to the engine wear and deposition of the suphur which form an acidic bi products that are harmful to the environment and gradually corroding of the engine. ASTM D2622 and ASTM D4294 determined the sulphur content of the diesel fuel.

Flash point: this is the lowest temperature at which petroleum vapor will ignite under low flame. This parameter is important for safe handling and storage of petroleum products. It is determined by ASTM D93.

Heating value: this parameter measures the energy available in the fuels when it burns. It affects the power output and the fuel economy. This value is determined by ASTM D240.

Lubricity: this is the ability of a liquid to lubricate. This parameter affects the life span of the engine components such as the fuel injection pumps.

Corrosivity: ASTM D130 is the copper corrosion and tarnish test. This analysis is conducted to minimize attack on metal in the distribution and storage network, and in the engine fuel system.

Water and sediment content: this can lead to increase in corrosion, plugging of filter and damage to engine. It is measured by ASTM D1796. The maximum limit of water and sediment is $0.005 \%$ by volume.

However, not all the aforementioned parameters of the diesel fuel were determined in this work. The parameters of the fuel that were determined in this work are the appearance, colour, boiling points ranges, flash points, density, and API gravity.

\section{Materials and methods}

Ten (10) samples of diesel fuel were randomly selected from different dispensing point and the samples were analysed to determine their characteristics and performances. Physical properties such as flash point temperature, boiling points ranges, flash points, density, and API gravity of the samples were determined and their results were compared with the standard specification criteria prescribed by the American Society for Testing Materials (ASTM), Department of Petroleum Resources (DPR) and the 
Standard Organization of Nigerian (SON) to attest their reliability.

\section{Determination of density}

Materials: samples of diesel fuel, measuring cylinder, and hydrometer.

Method: the diesel fuel sample was poured into the measuring cylinder and a hydrometer of required range prescribed for diesel fuel was inserted into the cylinder containing the samples of the diesel fuel and was allowed to stand for some minutes until it become stable or balance in the sample, the reading was then noted and recorded at that point. This procedure is repeated for density determination of the remaining samples.

\section{Determination of Flash point temperature}

Materials: samples of diesel fuel, Pensky Martens flash point tester consisting of test cup, test cover, and shutter, stirring device, heater, ignition source and thermometer.

Method: the test cup was cleaned and dried, and was then filled with the sample of diesel fuel to be analyzed to the level indicated by the filling mark of the cup, the lid was then placed on the cup to covered it firmly. The locking device was engaged properly then the thermometer was inserted to the space provided for it on the lid. The ignition source was opened and the source of ignition provides the flame, the flame was adjusted gradually which leads to rise in temperature, as the temperature raised to $60^{\circ} \mathrm{C}$, the stirrer was stirred at 120rpm (Revolution Per Minute). The lowest temperature, for diesel quality control analysis is $65^{\circ} \mathrm{C}$, as this temperature was reached the flame test was applied for every degree rise in temperature by lowering the flame into the vapour space of the cup and raised it quickly to its normal position until the flame turned to blue, then the temperature corresponding to the observed blue flame is the flash point temperature. The above procedure is repeated for the flash points temperatures of the remaining samples.

\section{Determination of boiling points of diesel fuel:}

Materials: diesel fuel samples, distillation tester, distillation flask and cork, Thermometer, cooling bath and warmed water.

Method: $100 \mathrm{ml}$ of diesel fuel was measured with the measuring cylinder and was poured into the distillation flask. The thermometer was fitted into the distillation flask and corked at the middle and the flask was then inserted into the distillation machine. The cooling bath of distiller was filled with warmed water so to ease the condensation of vapour to liquid. The measuring cylinder was placed at the collection unit of the distillation machine to collect liquid that condensed. Heat was applied to the sample via the heat source to generate vapor, as the vapor is generated it moves up and passed through the condenser that was situated through the cooling bath filled with warmed water to ease the vapourization and condensed the vapour to liquid which is collected via the measuring cylinder at the collection unit. The temperature that corresponds to the first drop of the distillate into the cylinder is the initial boiling point of the sample. This temperature was noted and recorded at the first drop of the distillate. The temperature that corresponds to $5 \mathrm{ml}, 10 \mathrm{ml}, 50 \mathrm{ml}$, and $90 \mathrm{ml}$ and $95 \mathrm{ml}$ recovery were noted and recorded. The recovery was recorded at the temperature of $357^{\circ} \mathrm{C}$. The final boiling point was also noted and recorded. The final recovery of the sample, the loss and residue were also noted and recorded. The above steps were repeated for the boiling points ranges of the remaining samples of diesel fuel.

\section{Results and Discussion}

Table 1 show that properties such as the appearances and the colours of samples 1 to 7 , are within the standard specification of the American Society for Testing Materials (ASTM), Department of Petroleum Resources (DPR) and the Standard Organization of Nigeria (SON). Samples 8 to 10 , are out of the standard specification requirement, this indicates that the samples may contained some adulterants that lead to the deviation of those properties. Because according to ASTM D1500, the colour of diesel fuel should not exceed 3.0, samples 1 to 7 , are within the standard specification range, but samples 8 to 10 have exceeded the standard specification requirement.

Table 2 shows the values of the specific gravity and the API gravity of the samples studied in this work. The table further reveals that, the values of the specific gravity of the samples are within the standard specification criteria. The standard specification range for density of diesel fuel is $820-870 \mathrm{~kg} / \mathrm{m}^{3}$ and the values of density of all samples including the samples that were suspected to be adulterated are within the standard specifications criteria. This shows that density is immaterial to attest the reliability of the 
products. The table also indicates that the lower the specific gravity of the samples, the higher the API gravity hence the lower the viscosity, carbon residue content and the higher the heat of combustion. Also the higher the specific gravity of the samples, the lower the API gravity hence high viscosity and carbon residue content is observe which leads to low heat of combustion.

Table 3 shows the results of the Atmospheric distillation profile. According to ASTM D975, Department of Petroleum Resources (DPR) /Standard Organization of Nigerian (SON) standard specification for diesel fuel boiling point range, the initial boiling point of diesel fuel should not exceed $190^{\circ} \mathrm{C}$, the recovery at temperature of $357^{\circ} \mathrm{C}$ should not be less than $91 \%(\mathrm{v} / \mathrm{v})$, the final boiling point, the residue and the loss should not exceed $385^{\circ} \mathrm{C}, 1.5 \%$, and $1.5 \%$ respectively. The table shows that samples 1 to 7 , are within the prescribed standard specification, this shows that the samples are unadulterated but samples 8 to 10 are out of the prescribed range, this means that, the samples 8 to 10 may contained some adulterants that lead to the deviation of their boiling point ranges.

Table 4 shows the results of the flash point analysis of the samples studied in this work. According to the Department of Petroleum Resources (DPR) and the Standard Organization of Nigerian (SON) for diesel fuel flash point analysis, the standard specification requirement ranges from $66^{\circ} \mathrm{C}$ to $120^{\circ} \mathrm{C}$. The table shows that all the samples of the Diesel fuel studied in this work are within the prescribed standard criteria. This shows that the fuels samples adhered to the safety handling requirement for storage and utilization, because if the fuels samples are less than the prescribed flash point temperatures, they are bound to ignite when expose to open flame.

Table 1 Results of physical analysis of the samples

\begin{tabular}{|c|c|c|c|c|c|c|c|c|c|c|}
\hline Test/samples & 1 & 2 & 3 & 4 & 5 & 6 & 7 & 8 & 9 & 10 \\
\hline Appearance & $\begin{array}{c}\text { Clear } \\
\& \\
\text { Bright }\end{array}$ & $\begin{array}{c}\text { Clear } \\
\& \\
\text { Bright }\end{array}$ & $\begin{array}{c}\text { Clear } \\
\& \\
\text { Bright }\end{array}$ & $\begin{array}{l}\text { Clear } \\
\& \\
\text { Bright }\end{array}$ & $\begin{array}{c}\text { Clear } \\
\& \\
\text { Bright }\end{array}$ & $\begin{array}{l}\text { Clear } \\
\& \\
\text { Bright }\end{array}$ & $\begin{array}{c}\text { Clear } \\
\& \\
\text { Bright }\end{array}$ & $\begin{array}{l}\text { Not } \\
\text { clear }\end{array}$ & $\begin{array}{l}\text { Not } \\
\text { clear }\end{array}$ & $\begin{array}{l}\text { Not } \\
\text { clear }\end{array}$ \\
\hline Colour & 1.5 & 2 & 20 & 2 & $2 n$ & 2 & 20 & 3.3 & 3.2 & 3.5 \\
\hline $\begin{array}{l}\text { Suspended } \\
\text { matter }\end{array}$ & Nil & " & "De & & & " & & $"$ & " & " \\
\hline
\end{tabular}

Table 2 Results of Density and the API gravity of Diesel fuel samples

\begin{tabular}{|c|c|c|}
\hline Samples & $\begin{array}{c}\text { Specific gravity } \\
\text { at } 60^{\circ} \mathrm{C}\end{array}$ & API gravity $\left(^{\circ}\right)$ \\
\hline 1 & 0.86 & 32.73 \\
\hline 2 & 0.86 & 32.48 \\
\hline 3 & 0.86 & 32.44 \\
\hline 4 & 0.86 & 32.35 \\
\hline 5 & 0.86 & 32.24 \\
\hline 6 & 0.86 & 32.60 \\
\hline 7 & 0.86 & 32.58 \\
\hline 8 & 0.83 & 39.99 \\
\hline 9 & 0.84 & 36.51 \\
\hline 10 & 0.86 & 33.02 \\
\hline ASTM D1298 & DPR/SON & $0.8200-0.8700$ \\
\hline
\end{tabular}


International Journal of Trend in Scientific Research and Development (IJTSRD) ISSN: 2456-6470

Table 3 Results of Atmospheric distillation profile of the gasoline samples

\begin{tabular}{|c|c|c|c|c|c|c|c|c|c|c|}
\hline $\begin{array}{c}\text { Volume } \\
\text { (mi) }\end{array}$ & $\begin{array}{c}\text { Samp } \\
1,{ }^{\circ} \\
\mathrm{T},{ }^{\circ} \mathrm{C}\end{array}$ & $\begin{array}{c}\text { Samp } \\
2 \\
\mathrm{~T},{ }^{0} \mathrm{C}\end{array}$ & $\begin{array}{c}\text { Samp } \\
3 \\
\mathrm{~T},{ }^{0} \mathrm{C}\end{array}$ & $\begin{array}{c}\text { Samp } \\
{ }^{4} \\
\mathrm{~T},{ }^{0} \mathrm{C}\end{array}$ & $\begin{array}{c}\text { Samp } \\
5 \\
\mathrm{~T},{ }^{\circ} \mathrm{C}\end{array}$ & $\begin{array}{c}\text { Samp } \\
{ }^{6} \\
\mathrm{~T},{ }^{0} \mathrm{C}\end{array}$ & $\begin{array}{c}\text { Samp } \\
{ }^{7} \\
\mathrm{~T},{ }^{0} \mathrm{C}\end{array}$ & $\begin{array}{c}\text { Samp } \\
{ }^{8} \\
\mathrm{~T},{ }^{0} \mathrm{C}\end{array}$ & $\begin{array}{c}\text { Samp } \\
9 \\
\mathrm{~T},{ }^{0} \mathrm{C}\end{array}$ & $\begin{array}{c}\text { Samp } \\
10 \\
\mathrm{~T},{ }^{0} \mathrm{C}\end{array}$ \\
\hline IBP & 170 & 170 & 170 & 170 & 170 & 170 & 170 & 135 & 150 & 140 \\
\hline 5 & 214 & 195 & 196 & 195 & 195 & 195 & 215 & 152 & 186 & 172 \\
\hline 10 & 235 & 215 & 215 & 215 & 215 & 215 & 235 & 178 & 205 & 208 \\
\hline 50 & 309 & 305 & 305 & 305 & 305 & 305 & 309 & 220 & 228 & 254 \\
\hline 90 & 360 & 355 & 356 & 355 & 355 & 356 & 360 & 270 & 272 & NIL \\
\hline 95 & 370 & 379 & 380 & 379 & 379 & 378 & 379 & NIL & NIL & NIL \\
\hline $\begin{array}{l}\text { Recovery } \\
\text { at } 357^{\circ} \mathrm{C}\end{array}$ & $\begin{array}{l}91 \% \\
(\mathrm{v} / \mathrm{v})\end{array}$ & $\begin{array}{l}91 \% \\
(\mathrm{v} / \mathrm{v})\end{array}$ & $\begin{array}{l}91 \% \\
(\mathrm{v} / \mathrm{v})\end{array}$ & $\begin{array}{l}91 \% \\
(\mathrm{v} / \mathrm{v}) \\
\end{array}$ & $\begin{array}{l}91 \% \\
(\mathrm{v} / \mathrm{v}) \\
\end{array}$ & $\begin{array}{l}91 \% \\
(\mathrm{v} / \mathrm{v})\end{array}$ & $\begin{array}{l}91 \% \\
(\mathrm{v} / \mathrm{v}) \\
\end{array}$ & NIL & NIL & NIL \\
\hline FBP & 378 & 380 & 382 & 380 & 380 & 379 & 380 & 272 & 271 & 256 \\
\hline TR & 97 & 97 & 97 & 97 & 97 & 97 & 97 & 90 & 92 & 88 \\
\hline Residue & 1.5 & 1.5 & 1.5 & 1.5 & 1.5 & 1.5 & 1.5 & 6 & 5 & 7 \\
\hline Loss & 1.5 & 1.5 & 1.5 & 1.5 & 1.5 & 1.5 & 1.5 & 4 & 3 & 5 \\
\hline
\end{tabular}

Table 4 Results of the Flash point analysis for the samples

\begin{tabular}{|l|l|}
\hline Samples & Flash point temperature $\left({ }^{0} \mathrm{C}\right)$ \\
\hline 1 & 70 \\
\hline 2 & 80 \\
\hline 3 & 82 \\
\hline 4 & 80 \\
\hline 5 & 80 \\
\hline 6 & 81 \\
\hline 7 & 80 \\
\hline 8 & 69 \\
\hline 9 & 68 \\
\hline 10 & 67 \\
\hline DPR/SON & 66 minimum \\
\hline SPECIFICATION & \\
\hline ASTM & D93 \\
\hline
\end{tabular}

\section{Conclusion}

Properties of the diesel fuel samples studied in this work were analysed experimentally to delineate the performance and the reliability of the fuels. The following findings were outlined.

Most of the diesel fuel samples in the area under study adhered to the standard specification requirements prescribed by the American Society for Testing Materials (ASTM) and are in line with the standard specification requirements of the Department of Petroleum Resources (DPR) and the Standard Organization of Nigeria (SON). The results of the study show that samples 1 to 7 are within the standard requirement; this means that they are unadulterated. However, most of the properties of samples 8 to 10 deviate from the standard specification criteria, this shows that they may contained some adulterant that lead to the deviation of their various properties. Therefore, samples 8 to 10 are adulterated.

Physical properties of the diesel fuel samples such as appearance and colours along are not enough to attest the reliability and the performance of the fuel. They can only identify the quality of the fuel. Therefore, they should not be used alone to judge the authenticity of the fuel. They should be used in collaboration with other critical properties to ascertain the authenticity of the fue.

Boiling point range of the diesel fuel is an important critical parameter that entails the behaviours of the fuel during storage and usage and is a good parameter that attests the reliability and the performance of the fuel.

Flash point analysis of the diesel fuel samples entails only the safety handling and storage requirement of the fuel. However, this analysis alone does not attest the authenticity of diesel fuel.

The results of the study show that the specific gravity of the diesel fuel samples studied in this work are within the standard specification requirement. This indicates that the specific gravity (density) of diesel fuel is immaterial in judging the reliability and 
performance of the fuel samples studied in this work. Because both the adulterated and unadulterated samples of the Diesel fuel studied in this work are within the standard specifications criteria for density of Diesel fuel.

\section{References}

1) ASTM D287-12b. (2017). Standard Test Method for API Gravity of Crude Petroleum and Petroleum products by (Hydrometer method). ASTM International, West Conshohocken, PA. Retrieved from www.astm.org.

2) ASTM D1298-12b. (2017). Standard Test Method for Density, Relative Density and API Gravity of Crude Petroleum and Liquid Petroleum products by thermometer method. ASTM International, west Conshohocken, PA. Retrieved from www.astm.org.

3) ASTM D86-17. (2017). Standard Test Method for Distillation of petroleum products and Liquid fuel at Atmospheric pressure. ASTM International, west Conshohocken, PA. Retrieved from www.astm.org.

4) ASTM D93-18. (2018). Standard Test Method for Flash Point by Pensky-Martins close cup Tester. ASTM International, west Conshohocken, PA. Retrieved from www.astm.org.

5) ASTM D1500-12. (2017). Standard Test Method for Colour of Petroleum Products (ASTM Colour scale). ASTM International, west Conshohocken, PA. Retrieved from www.astm.org.

6) ASTM D978-18. (2018). Standard Test Method for Diesel fuel. ASTM International, west
Conshohocken, PA. Retrieved from www.astm.org.

7) ASTM D2699-18. (2018). Standard Test Method for Research Octane Number of spark ignition fuel. ASTM International, west Conshohocken, PA. Retrieved from www.astm.org.

8) Bharath, LV, \& Himanth, M. (2017). Review on the Detection of Fuel Adulteration through Sensor based Techniques. International Journal of Science and Research. 7(9), 447-451.

9) Changes in Diesel Fuel. (2007). Retrieved from http://biodiesel.org/docs/ffs-performance_usage/

10) Devold, H. (2010). Oil and Gas production handbook: An introduction to oil production. ABB Oil and Gas Limited.

11) Diesel fuel. (2010). In A. Augustyn et al. (Eds), Encyclopedia Britannica. Retrieved from https://www.britanica.com>technology.

12) Diesel Fuel Technical Review. (2007). Retrieved from https://www.chevron.com>document.

13) Hsu, C.S. (2000). Diesel Fuel Analysis. In R.A. Meyers (Ed). Pp.6613-6623. Chichester, John Wiley and Sons Limited.

14) National Bureau of Statistics: petroleum products consumption statistics. (January-March, 2016). Retrieved from http://nigerianstat.gov.ng/download.

15) Jukic, A. (2013). Petroleum Refining and Petrochemical Processess. Faculty of Chemical Engineering and Technology. Retrieved from https://www.fkit.unizg.hr/download/respository/. 